\title{
SHORT-TAILED SHREW \\ APPARENT CAUSE OF MORTALITY OF EASTERN SCREECH-OWL
}

ROBERT W. NERO, Wildlife Branch, Box 24, 1495 St. James St., Winnipeg, Manitoba. R3H OW9

Although domestic cats are said to refrain from eating shrews because of their strong scent glands, they occasionally kill and bring them home. Owls of most species, on the other hand, routinely consume shrews. ${ }^{1,3}$ When it's too cold for mice, shrews, with their high metabolic rate and constant need for food, may be out foraging. Last winter, a Short-tailed Shrew came to search for seeds under our bird feeder, coming out from under the snow, crossing a sidewalk, and burrowing into the snow again next to our house. On two occasions, my wife saw it doing this from our living room window. It has since fallen victim to our neighbor's cat, much to my dismay. This is not the first shrew noticed by us at our feeders. One that I captured several years ago was used for two winters by Herb Copland and myself as a live lure for Great Gray Owls. It relished sunflower seeds. Last January, after a long cold spell, I found the distinctively splay-footed trail of a Short-tailed Shrew running for 30 paces on top of the snow. This was in a weedy field a few kilometres south of our home. Since Meadow Voles were plentiful last winter, it was expected that shrews, which prey on voles and mice, may have been more abundant than usual.

A Short-tailed Shrew, watched coming to another feeder almost daily by Ken Bachynsky at his home in this same area of Winnipeg, met its death when attacked by an Eastern Screech-Owl. The owl was first seen about 8:30 a.m. on 15 January 1994 , lying on the snow beneath a feeder. When the frozen bird was picked up, it had its prey stuck to its feet. Ken told me that this large dark "mouse" had been scrounging bird seeds beneath their feeder ever since the first snowfall. Usually, it was seen in the early evening, at about the same time of day as the one in our yard. He had believed it to be a mouse or vole. When the frozen duo were brought to the Wildlife Branch on 17 January in hopes of getting a possession permit, the true identity of the owl's prey was discovered. Gordon G. Graham advised Ken that the Eastern Screech-Owl was on a list of species not admissible for private use, and then brought this matter to my attention.

When examined by Graham the owl "appeared almost alive, for it was in perfect condition, ear tufts erect, eyes partly open (though glazed!), wings lowered and slightly out from the sides, tail fanned, plumage immaculate. It looked as if it had been mantling its prey." I looked at the frozen carcass the next day. At first glance the shrew appeared to be held by the bird, but the owl's feet were withdrawn and its tightly clenched talons were pressed on top of the shrew which had its head 
facing toward the owl's right. The owl apparently died after it captured the shrew, and while still crouching upon it. The owl and the shrew were frozen together by melted snow and blood. The shrew had a talon puncture mark on the left flank, its left front foot was almost severed, and there was a bite mark, with torn skin, on the right side of the back of the neck. That bite to the neck, or back of the head, is usually made by an owl shortly after seizing prey. It is the killing blow. This wound appeared to be the source of the blood on the owl's bill, right belly plumage and right foot. A small wound on the inside fleshy part of the owl's right foot may have been caused by the shrew. The owl, a grey-phase adult female (ovary present), weighed only 140.2 grams. It was thin and lacking any fat. The shrew, an adult male, weighed 26.6 grams.

The Short-tailed Shrew is a robust, muscular creature, a tough adversary to subdue, even for domestic cats. Although this is speculative, the evidence suggests that the owl was bitten by the shrew before the owl killed it. The shrew's bite presumably paralyzed the owl, but not before the owl finished off the shrew, and the owl then froze to death. The fact that the owl had let go of the shrew, but was still crouched upon it, suggests that death took place quickly. It was cold that night. Environment Canada, as determined by Graham, recorded a minimum temperature of $-35^{\circ} \mathrm{C}$ (mean temperature $-31^{\circ} \mathrm{C}$ ), with a wind chill of 2200.

The Short-tailed Shrew, as I pointed out in a Blue Jay article in 1956 , is a venomous mammal. ${ }^{7}$ Zoologist Charles J. Maynard, apparently the first person to feel and record the effects of being bitten by this shrew, made good note of his experience as early as $1889 .^{5}$
Maynard's detailed description of that edifying experience was later quoted at length in a book on Wisconsin mammals. ${ }^{4}$ I'm impressed by the fact that Maynard, although "suffering acutely" from a burning sensation, shooting pains, swelling, etc., where bitten on the fingers of both hands and on his arms, didn't drop the shrew! He wanted to study it alive, so he continued to hold the struggling animal as he hurried to his house, where he "placed the shrew in an improvised cage." Those early naturalists were a determined lot. Folks may have thought that Maynard's report was exaggerated, for more than 50 years passed before anyone followed up on his observations. Mammalogist Oliver $P$. Pearson discovered that a poisonous substance similar to cobra venom is contained in the shrew's submaxillary salivary glands. When extracted and injected by Pearson into laboratory mice "convulsions were followed by death, due to respiratory failure."9

It has been established that a shrew's glands contain enough poison to kill 200 mice. ${ }^{1,4,9,11}$ The venom serves to subdue the shrew's prey primarily mice and voles, and even, surprisingly, small rabbits. ${ }^{10}$ "Although mice usually form only a small item in the normal shrew diet, short-tailed shrews may prey upon voles to a much greater extent when meadow voles (Microtus pennsylvanicus) are abundant. In one study, mouse remains were found in 56 per cent of the shrew stomachs examined. During the winter of 1942-43, vole populations near Ithaca, New York, reached eighty per acre; and by spring short-tailed shrews were thought to have accounted for fourteen to twenty-seven voles per acre."1

The cases in which a raptor dies as a result of an encounter with prey 
must be rare, but there have been a few such reports. Bent, for example, refers to an observation of a Redtailed Hawk "attacking a rattlesnake, which bit the hawk twice and killed it. As this was in Nebraska it probably was one of the eastern redtails and perhaps not accustomed to rattlesnakes." Occasionally, even nonraptorial birds may run afoul of unusual prey items - Blue Jay readers may recall the curious case of a Ruffed Grouse that choked to death on a mouse! ${ }^{8}$

The Eastern Screech-Owl is itself no slouch, taking, in addition to shrews and other small mammals, a wide variety of birds including one incredible, though well-documented, example of a Ruffed Grouse. ${ }^{3}$ A recent study of a small sample of prey remains found in fall at Screech-owl roost sites (nest boxes) just south of Winnipeg found no shrews; $77 \%$ of the biomass represented by the prey remains was accounted for by birds. ${ }^{6}$ Screech-owls are fairly common in Winnipeg, nearly a dozen having been turned in to the Manitoba Wildlife Rehabilitation Organization in winter 1992-93, and about five so far this winter. The extent to which they prey upon birds at or near feeders is not known, mostly because of their nocturnal habits, but there seem to be increasing reports of Screechowls in this area. One can surmise that the Screech-owl found by Ken Bachynsky had been attracted to that site by the numerous birds drawn to his feeder including, as I was informed, a dozen House Sparrows, a few Blue Jays, Black-capped Chickadees, White-breasted Nuthatches and others (plus Cottontails!).
I am indebted to Ken Bachynsky for making this report possible. Gordon G. Graham provided useful assistance. My thanks to both.

1. BANFIELD, A.W.F. 1974. The mammals of Canada. Univ. Toronto Press. $438 \mathrm{pp}$.

2. BENT, A.C. 1937. Life histories of North American birds of prey. Pt. 1. U.S. Natl. Mus. Bull. 167. Dover reprint 1961.409 pp.

3. - 1938. Life histories of North American birds of prey. Pt. 2. U.S. Natl. Mus. Bull. 170. Dover reprint $1961.482 \mathrm{pp}$.

4. JACKSON, H.H.T. 1961. Mammals of Wisconsin. Univ. Wisconsin Press. 504 pp.

5. MAYNARD, C.J. 1889. Singular effects produced by the bite of a shorttailed shrew, Blarina brevicauda. Contributions to Science 1 (2):57-59. (Not seen)

6. MAZUR, K.M. 1992. Fall food of the Eastern Screech-owl in Manitoba. Blue Jay 50:33-35.

7. NERO, R.W. 1956. Additional records of the Short-tailed Shrew in Saskatchewan. Blue Jay 14:45-46.

8. - 1968. An attempt by a Ruffed Grouse to eat a mouse. Blue Jay 26:189-190.

9. PEARSON, O.P. 1942. On the cause and nature of a poisonous action produced by the bite of a shrew (Blarina brevicauda). Journ. Mamm. 23:159166.

10. PETERSON, R.L. 1966. The mammals of eastern Canada. Oxford Univ. Press, Toronto. 465 pp.

11. SCHWARTZ, C.W., and E.R. SCHWARTZ. 1959. The wild mammals of Missouri. Univ. Missouri Press, Kansas City. 341 pp. 